\title{
Analysis of the Russian youth slang by native Chinese
}

\author{
Zhang Wei ${ }^{*}$ \\ Ryazan State University named after S. Yesenin, 46, Svobody str., Ryazan, 390000 Russia
}

\begin{abstract}
With the development of technology and information, language has changed as well. It is no longer important to follow the literary norm. It is important to be able to communicate effectively and to remove communication barriers. Russian students studying in China or Chinese students studying in Russia use slang or fancy words in the intercultural communication. Russian youth slang as a specific linguistic phenomenon has attracted an increasing number of researchers. Among them are scientists, undergraduates and graduate students, as well as teachers of the Russian language. People are interested in this linguistic phenomenon because of its specificity and linguistic fashion for slang lexical units. When analyzing a foreign language (e.g., Russian), native speakers of Chinese use the same or similar linguistic phenomena for a comparative analysis. This article aims to compare lexical units of modern Russian youth slang with Chinese ones. The article concludes that language fashion exists in both language systems.
\end{abstract}

\section{Introduction}

Any language and its vocabulary are rapidly developing. Vocabulary is the collection of words that make up language. In other words, vocabulary is not only words, but also phrases - idioms, phraseological units, familiar words, etc.

Lexicology is a linguistic discipline that studies vocabulary. In lexicology, the word is studied in connection with other words [8, p. 100]. All words constitute vocabulary. The lexical unit is the same as the other linguistic levels (phonemic, lexical and structural). They can be compared by a number of characteristics. They interact with each other and are organized in a certain way, i.e. form a system. They can be compared with other hierarchical units. The branch of linguistics that studies lexical systems is called lexicography. It studies the relationship between words and similar units at the lexical level, i.e. it studies the relationship between words and units similar to them, i.e. with the same root words.

National vocabulary includes all lexical units: professional, dialectal, slang, and literary words (see diagram) [8, p. 100].

Language is a living organism which is changing in different ways: new words appear, old ones disappear, the boundary between literary and non-literary words changes, so it is reasonable to assume that youth slang as part of languages will continue to change and develop, playing its role in the history of language.
Thus, fashionable among "neologisms" can be called only those words that reflect the concept of fashion, reflect people's desire for novelty and circulate with great speed in society, while non-new words are also fashionable if they fall into the hot spots of society, express the meaning of fashion and reflect a fresh style of language. If from the point of view of the characteristics of the "fashion" itself, fashion is "tied to time", it has a period of time, and therefore fashion words have a strong sense of time. Any social fashion is subject to a time constraint, which is usually twofold: historical continuity and modern transience. The so-called historical continuity means that fashion is not interrupted throughout history, that there are always fashions, or several fashions, or alternating fashions, in different social dynasties and at different stages of the development of society. This applies to fashion in general. If we consider individual manifestations of fashion, then each fashion at a certain stage does not last long, they are popular for a while, but often short-lived, because fashion is always presented in a new form to be appreciated and imitated, so that it can spread widely and lead the trend. However, most new things are affected by time. What is new and popular today may be outdated tomorrow.

\section{Materials and methods}

The young generation carries the important task of national development and prosperity. Some see youth speech as an important mechanism of intellectual

\footnotetext{
Corresponding author: xiaotuzhangwei@163.com
} 
activity, others as a historically established form of communication, and some see speech as a means of self-expression. Speech is constantly evolving, and young people play an important role in this. Therefore, it is necessary to study youth slang.

International relations between China and Russia have a long history; under the "one belt and one road" policy more and more Chinese people, including experts, scholars and graduate students, have begun to study the juxtaposition of Sino-Russian linguistic phenomena in linguistics. The phenomenon of Russian youth slang attracts Chinese students who are eager to learn it. This is due to the fact that the Russian young people make up the majority of the population and because slang words perform their own expressive function.

V.S. Elistratov demands to bring the study of slang to the broad and fertile field of linguocultural colony and linguophilosophy; he considers slang as a unit of interaction between language and culture [6, p. 672].

Youth is an important component of society, they provide social ties and have a direct impact on the development of society. E.V. Ataeva and D.S. Malysheva claim that "along with media language, language of youth is the most influential sphere of mass communication in terms of influence on modern living speech [1, p. 209].

\section{Results and discussion}

The vocabulary of a young person is often determined by linguistic fashion, that is, the desire to use certain words only because it will make him feel "peculiar" or "fashionable".

Table 1. Russian youth slang and their English equivalents.

\begin{tabular}{|c|c|}
\hline \multicolumn{2}{|c|}{ Nouns } \\
\hline Slang units & translation \\
\hline инкам & income \\
\hline кейс & case \\
\hline скилл & skill \\
\hline солд-аут & Sold out \\
\hline тренинг & training \\
\hline рисёрч & research \\
\hline роадмап & plan \\
\hline рэндом & random \\
\hline таргет & target \\
\hline фикс & fix \\
\hline эйгар & Staff manager \\
\hline \multicolumn{2}{|c|}{ Verbs } \\
\hline ливнуть & leave \\
\hline чекать & check \\
\hline \multicolumn{2}{|c|}{ Adverbs } \\
\hline крипово & creeply \\
\hline отпад & well \\
\hline
\end{tabular}

(Source: www.yandex.ru )

It is well known that modern linguistic processes are rapidly developing. Today, the most powerful factor influencing the Russian language is linguistic fashion.

Language fashion is an expression of language tastes, language preferences and assessments. It is a new and prestigious model of language use. Being linguistically and culturally determined, the phenomenon influences them. Language fashion and language tastes go hand in hand and complement each other.

Youth slang in Russian is not just limited to these examples.

Chinese and Russian are two different languages, but youth slang as a special form of language is present in both languages. At the same time, the processes of replenishing youth slang are similar. More precisely, in Chinese there is no concept of youth slang, but there are concepts of slang and fashionable words.
In the Chinese language, there is linguistic fashion. Hre are popular Chinese slangisms and their English equivalents.

Language is a social phenomenon closely related to the development of society. In the era of informatization and economic globalization, many borrowed words inevitably entered the Russian youth slang. The most representative of them are Anglicisms.

Russian Russian youth slang as a source of new words in the traditional language will make the study of the Russian language more systematic and comprehensive.

Currently, scientists give several concepts and definitions of slang, they often contradict each other. However, the definition of V.A. Khomyakov reveals the concept of slang most fully. In his opinion, slang is a relatively stable lexical layer for a certain period of time, 
which is characterized by a wide scope of use and stylistically pronounced labeling. These are various parts of speech, nouns and adjectives, verbs that denote signs, processes, phenomena and objects. Khomyakov believes that slang is a component of expressive vernacular, which is a mandatory element of the literary language. At the same time, the component is heterogeneous in its origins and the degree of approximation to the literary standard[10, p. 394]

The attitude to borrowing is twofold. Native speakers were divided into two camps. Some believe that Russian speech in its original form is lost when replenishing the vocabulary with foreign words. There is an oversaturation of speech with barbarisms. Others have a different point of view. In the process of borrowing, they see the enrichment of the Russian language. During the disputes, the polemicizing parties do not take into account the fact that many words have become firmly part of the Russian language, since they have no equivalents.

Young people are the most promising group of society. The linguistic competence and linguistic behavior of this group of society largely influence the development of language, the emergence and existence of various forms of language. At the same time, the layer of youth vocabulary is extremely mobile, it has an uncodified character and obeys, first of all, the sociolinguistic norm.

In recent years, radical changes in the category of youth slang are mainly reflected in its lexical composition, while grammar and ways of forming new lexical units are not affected. The main and most effective way of forming new lexical units of youth slang is borrowing from foreign languages. It is also worth noting the methods of metaphorization, abbreviation, affixation, metathesis and phraseological.

In different years, words from other languages have entered the Russian language. This was possible in the process of building economic, political, and cultural ties with other countries. At the beginning of the XXI century, Russian and English languages are in contact with each other more than others. English is an international language, and therefore Anglicisms enter the Russian language in large quantities. The influence of English on the Russian language turned out to be one of the most stable and affected almost all spheres of modern human activity. At the turn of the XIX and XX centuries, sports vocabulary began to actively penetrate the English language (finish, start, sport, athlete, football, basketball, volleyball, boxing, hockey). Today we can talk about the use of foreign vocabulary in all spheres of human activity: industry, business, education, trade, etc.[11, p. 48]

\section{1. 奥利给}

cool.

2. 备胎

Spare wheel.

Meaning: The fallback.
3.标题党

Literally: theme party.

Meaning: The creators behind the clickbait. A catchy blog post or forum post title to attract attention that does not match the content.

4.不忘初心

not forgetting about the original goal; stay true to the original purpose.

5.吃瓜群众

Literally: "the crowd eating a watermelon." Figuratively: ignorant of the masses, used in offline situations.

\section{6.城市套路深，我要回农村}

Literally: there is a deep set of standard methods in the city, I want to go back to the village.

Meaning: Everything is too tricky in the city, I want to return to the village.

\section{7.单身狗}

Literally: dog, loner. Figuratively: bachelor.

8.低调或高调

Be humble or behave humble or do that publicly.

9.钉子户

nail landlord (in China they call people who do not want to move from the land on which new development is planned, because of disagreement with compensation).

10. 打鸡血.

Literally: Inject yourself with chicken blood. Figuratively: to be excited, hot.

11. 此聊

Translation: Have an awkward conversation. Meaning: One of the parties is not very talkative, which leads to a breakdown in communication

12.干饭人; 干饭魂

Translation: people who eat actively.

Meaning: People who can just eat and have a meal, do nothing.

13. 杜精

brawler.

14. 好烸呦

The words come from the song. It is used to express a very happy or excited state.

\section{5.僵尸粉}

Low-lived subscribers on social networks, or winding up subscribers (fake accounts).

16.惊不惊喜, 意不意外

Literally: Was it a surprise? Was it unexpected?

Meaning: events were unexpected.

17.可盐可甜

Literally: salty and sweet. Figuratively: to be confident, nice.

18.你品, 你细品

Feel, think.

19.你的良心不会痛吗

the question serves as a rebuke to those who are indifferent to their fans.

20. 柠檬精

to feel envy.

21.贫穷限制了我的想象力 
it is often difficult for ordinary people to imagine how the rich live, what their interests and entertainment are..

\section{2. 神操作}

expresses surprise and admiration for what is happening on the screen or in a conversation. At the same time, it has a slight tinge of mockery.

\section{3.神回复}

Literally: "holy or divine commentary." About large, detailed, useful and often unexpected comments on forums and blogs.

\section{4. 神兽}

Literally: a mythical animal. Meaning: child. How internet memes are used in relation to naughty, moody and stupid children.

25. 是个狼人

Literally: wolf-man. Meaning: The ruthless.

26. 笋都被你夺完了

Literally: You have taken all the bamboo shoots. Meaning: very snide, in Chinese bamboo shoots and snide are homonyms.

27.U1S1

To tell the truth without any lies.

28. 我太难了

How hard it is for me!

29. 我不要你觉得, 我要我觉得

I make all decisions

30. 小丑竟然是我自己

ridicule yourself. Keep smiling even when life isn't happy.

\section{1.爷青回}

youth is back.

32.硬核

cool.

33.扎心了, 老铁

This is to complain.

34.直播带货

entertainment online broadcasting for the purpose of selling goods.

\section{Conclusion}

Youth slang is a subsystem in linguistics, although it is considered an informal, informal language that is outside the literary norm. Russian youth slang is a linguistic phenomenon. Slang can be called unstable speech, since it has a time-limited existence and, as a rule, is not transmitted from generation to generation. Young people often intentionally highlight slang expressions in their speech, focus attention on them in order to emphasize their "advancement", while it is young people who are able to control and regulate the use of "fashionable" slang words, refraining from them or, conversely, activate them at their own discretion.

The words listed above very quickly became popular among young people, in some cases they even went beyond youth slang. However, these lexemes remain stylistically labeled, are outside the literary norm and to a certain extent pose barriers to communication. Such words will not be included in the dictionary of codified vocabulary.

Youth slang reflects linguistic fashion. We can explore slang units: buzzwords in Russian and Chinese slang. The study of the Russian youth slang expands the ideas of foreign students about Russian, emphasizes the mental originality. An analysis of Chinese youth slang contributes to a deeper understanding of the linguistic fashion of Russian youth slang.

The language fashion is a category that is capable of regulating the "language behavior" and demonstrating the level of education and intelligence, since it divides language means by the degree of prestige, which depends on taste, aesthetic assessment of objects and phenomena.

Language fashion, which was discussed above, is considered to a certain extent the category that is able not only to regulate the "language behavior" of a person, but also to demonstrate the level of education and intelligence, since it ensures the separation of linguistic means according to the degree of prestige, which in turn depends on the taste of a person, his ability to aesthetic evaluation of objects and phenomena of reality.

\section{References}

1. E.V. Ataeva, D.S. Malysheva, On discourse words in the speech of young people Bulletin of the Faculty of Humanities, Ivanovo State University of Chemical Technology, 4 (2019).

2. G.Yu. Alimova, Youth slang and colloquial speech in modern linguistics Young Scientist. 12, $606-608$ (2017)

3. N.D. Arutyunova Anomalies and language Questions of linguistics, 3, 3 - 19 (2007)

4. K.V. Burova Specificity of anglicisms in youth slang Innovative technologies in teaching foreign languages: from theory to practice, 98 - 103, (2018)

5. M.V. Volosova, Functions of anglicisms in modern Chinese youth slang, Language. Literature. Culture 6, 87-99 (2015)

6. Elistratov V. Argo and culture Dictionary of the Moscow argo: Materials 1984-1990 (Moscow, 1994)

7. N.V. Nevtyago, M.V. Duzenli, Lexicology of the modern Russian language: a short course for foreign students: study guide. (M., FLINT. Yekaterinburg: Ural Publishing House. University, 2017).

8. V.V. Khimik The language of modern youth. Modern Russian speech: state and functioning: Collection of analytical materials. (St. Petersburg State University, 2004).

9. V.A. Khomyakov, Introduction to the study of slang - the main component of the English vernacular (Vologda, 2001) 
10. V.A. Khomyakov Non-standard Vocabulary in the structure of the English language of the national period, PhD dissertation (Leningrad, 1980).

11. Zh. V. Likhacheva Ways of borrowing in modern Russian by the example of youth slang, Science of man: humanitarian studies, pp.48-52 (2017) 